\title{
The Use of Affiliate Marketing in Improving Pegipegi Sales
}

\section{Penggunaan Affiliate Marketing dalam Meningkatkan Penjualan Pegipegi}

\author{
R. A. Emilia Natarina1, Cendera Rizky Anugrah Bangun² \\ ${ }^{1}$ STIKOM LSPR Jakarta, Intiland Tower Lt. 6, J1. Jend. Sudirman Kav. 32, Jakarta \\ 10250, Indonesia \\ ${ }^{2}$ Study Program of Strategic Communication, Faculty of Communication Sciences, \\ Universitas Multimedia Nusantara, Jl. Scientia Boulevard, Tangerang, \\ Banten 15811, Indonesia \\ *Corresponding author, e-mail: cendera.anugrah@umn.ac.id
}

\begin{abstract}
The changes in people's purchasing patterns from offline to online cause companies to change the type of their business which also affects the changing of marketing strategy. One of the marketing strategies used by the OTA (Online Travel Agent) industry is affiliate marketing. This study was conducted to find out how Pegipegi affiliate marketers used the digital marketing to help market OTA products in the digital media they use to help provide sales. The method used in this study is qualitative with the case study of Pegipegi affiliate marketers. The data collection was conducted by interviewing. The results of this study indicate that the basic understanding of how to market Pegipegi products through blogs, how to market blog through Google Ads and Facebook Ads, as well as the understanding on the functions of each affiliate marketing tools play an important role in the success of a marketer of Pegipegi affiliate.
\end{abstract}

Keywords: Affiliate Marketing, Affiliate Marketers, Digital Marketing, Online Sales, Online Travel Agent.

\begin{abstract}
Abstrak
Perubahan pola pembelian masyarakat dari offline ke online menyebabkan perusahaan harus mengubah bentuk bisnis mereka yang juga mempengaruhi berubahnya strategi pemasaran. Salah satu strategi pemasaran yang digunakan oleh industri OTA (Agen Perjalanan Online) adalah affiliate marketing. Penelitian ini dilakukan untuk mengetahui bagaimana pemasar afiliasi Pegipegi menggunakan pemasaran digital untuk membantu memasarkan produk OTA di media digital yang mereka gunakan sehingga turut membantu penjualan. Metode yang digunakan dalam penelitian ini kualitatif dengan studi kasus pemasar afiliasi Pegipegi. Pengumpulan data dilakukan dengan cara wawancara. Hasil penelitian ini menunjukkan bahwa pemahaman dasar tentang bagaimana cara memasarkan produk Pegipegi melalui blog, bagaimana cara memasarkan blog melalui Google Ads dan Facebook Ads, serta pemahaman akan fungsi dari setiap alat pemasaran afiliasi berperan penting pada keberhasilan seorang pemasar afiliasi Pegipegi.
\end{abstract}

Kata Kunci: Affiliate Marketing, Pemasar Afiliasi, Pemasaran Digital, Penjualan Online, Agen Perjalanan Online.

\section{Introduction}

The digital revolution encourages marketers to rethink their communication strategies. The ease of reaching consumers more effectively attracts more marketers to use the internet as their marketing strategy. The impact of the social media power is not only felt by individuals, but also felt by entrepreneurs. It can be seen that almost all

Article History: Received January 15, 2019; Revised February 08, 2019; Accepted May 28, 2019; Published July 30, 2019 
companies in the world, especially in Indonesia, use the internet as the companies existence media, as information media, and communication media between the companies and their publics (Putri \& Maulida, 2017). Communication technology has the role of overcoming the long distance differences that are not achieved simply by speaking in normal distance.

The growing trend of searching for products and services via online also requires producers and marketers to provide online stores, including conventional tourism activists such as travel agents who transform their business into Online Travel Agent (OTA). According to Rudiana Jones, Founder of the Indonesian Tour Leaders Association (ITLA) \& Wita Tour, this is the time for travel agent to explore the digital world so that it can be accessed from anywhere (Nursastri, 2016).

In the future, OTA in Indonesia is predicted to grow more rapidly in line with the Indonesian Government's plan to digitize the objects and all related to Indonesia tourism. Minister of Tourism Arief Yahya stated that this was the momentum to go digital and the Ministry of Tourism seriously digitalized all lines to facilitate the Indonesian tourism industry to develop (Setiawan, 2016).

Globally, the internet began to develop rapidly in 2000. According to Belch \& Belch (2015), one of the supporting factors for the development of the internet is the increasing of the consumers' desire to capture information easily and the presence of media to find and buy products/services via the internet also attracts people to use the internet (Belch \& Belch, 2015).

According to Fill (2013), the Internet has two effects on marketing, namely distribution and communication (Fill, 2013). With the presence of the internet, producers and marketers can directly distribute their products to consumers so they can replace or complete the existing distribution channels. The second impact is communication, where the internet allows producers and marketers to reach large audiences and provide a variety of information. Cyber presence will bring business to a time where buying and selling activities are more automatic and easy (Kotler, 2001). Businesses will connect each other and with their customers on a virtual network. Sellers will find it easier to identify potential buyers, while buyers will find it easier to identify the best sellers and producers. With the presence of the Internet in everyday life, consumers can meet their needs more quickly and easily with fewer obstacles (Ryan \& Jones, 2009).

In the digital economy era, the supporting factors such as time, geography, location, and storage of goods in physical form become irrelevant. Consumers want products quickly and right away. Therefore, marketers must engage in new ways. One of the online marketing strategies used by OTA and e-commerce businesses to find consumers and communicate their products is affiliate marketing. Finding new customers for e-commerce businesses can be quite costly, even in an online world where marketing cost is cheaper than the offline world (McPheat, 2011). In the online world, business people and marketers can pay for online advertising based on their performance, through affiliate marketing strategies.

The existence of this Customer to Customer (C2C) affiliate marketing member certainly contributes revenue and increases the sales of OTA products or services. Based on the results of interviews between the researchers and the Alliance Marketing Supervisor of Pegipegi, Kristy Karlinda, and the Alliance Officer Pegipegi, Qory Kurnia, the affiliate marketing program has just been implemented by Pegipegi in early 2013. The initial aim of the program was to promote Pegipegi products namely airline 
ticket and hotel. But on August 2016, the affiliate partners of Pegipegi also marketed train tickets as the newest product of Pegipegi. The affiliate partners of Pegipegi also have several ways to promote Pegipegi products on their sites or social media accounts, namely through text links, banners, and widgets. The members of this affiliate are not even obliged to have a blog or personal site to join, just by having Facebook account for promotional media.

Therefore the researchers are interested to examine how the successful affiliate marketers make personal sales to their buyers. The researchers also want to know what sales techniques are used by these outstanding affiliate marketers, apart from the techniques and the promotion/ sales media that have been prepared by Pegipegi, so that their personal sales techniques can be applied by the other affiliate marketers who are considered not too active yet.

The digital marketing concept was first introduced in 1990s (Kingsnorth, 2016). Banner advertising was put into use in 1993 and the first web crawler was created in 1994, where the search engine optimization (SEO) era began. According to Kaufman and Horton (2015), digital terms are often paired with tools and actions that appear in everyday life. Kaufman and Horton then define digital marketing as a marketing action that relies on digital media to carry out its functions specifically or complete the intended purpose. The media referred to in digital marketing are channel, tool, method, or device. Kaufman and Horton mention internet, smartphones and tablets as some examples of digital media, including applications that use the internet; television and radio are also considered as digital media because the two media use digital signal to broadcast the shows (Kaufman \& Horton, 2015). Tarigan and Sanjaya (2009) define digital marketing as marketing activity, including branding that uses various web-based media such as blog, website, e-mail, adwords, or social networks (Sanjaya \& Tarigan, 2009).

According to Fill (2013), the rapid interactivity and two-way communication as the impact of technological progress requires communication strategies and new understanding of how to communicate with the target audience. The ability to interact directly is the key feature offered by digital media and makes it different from traditional media (Fill, 2013). This interaction does not only provide realm for the target audience to receive and respond to information, but also to share knowledge and create content. Meanwhile, Tarigan and Sanjaya highlight the impact of the digital world is the loss of differentiation in the presence of increasingly asymmetric information (Sanjaya \& Tarigan, 2009). This is because the market can directly see and compare the value of the existing differentiation between certain products or services. The digital world provides equal opportunities for every products to be known. This is becoming increasingly extraordinary with the emergence of various websites or blogs that are independent in providing ratings on products and services. The marketing changes resulted from the development of digital marketing also have impact on producing new characters of online consumers. According to Ryan and Jones (2009), there are five online consumer characters, namely: First, digital consumers are more comfortable with the media used because they can be more efficient and effective. Content delivered by marketers must be in accordance with the wishes of consumers and quickly delivered. Second, digital consumers want to get various information in a variety of sources in a short time. Third, consumers have full control of their activities online. If the site they visit is not in line with expectations, they will quickly end the use. Fourth, the nature of digital consumers can change. The development of the internet does not eliminate the 
concept of brand or vendor loyalty, but reduces its meaning. With the ease of finding information and making comparisons, consumers can get new choices instantly. Fifth, digital consumers are vocal. Online consumers often interact each other through writing review, blog, social networks, online forum and communities, to share their positive and negative experiences (Ryan \& Jones, 2009).

Ryan and Jones state in their book that affiliate marketing is a web-based marketing practice in which business people give their affiliate members rewards for each click or consumer resulted from the promotion efforts of affiliate members. If it is defined more simply, affiliate marketing is an activity to increase traffic from one site to another site to get a reward (Ryan \& Jones, 2009). Meanwhile, McPheat defines affiliate marketing as a performance-based marketing communication strategy, the tariff for the advertising depends on the performance generated by the ads (McPheat, 2011).

In this case, the merchant only needs to pay the site or social media account owner if the ads give profit. If online advertisers generally have to pay in advance, in the affiliate marketing scheme, new merchants spend money if site or social media account visitors make purchases or fill out forms. The providers of affiliate marketing program and affiliate marketers in this case rely on cookies for the calculation of transactions (Fill, 2013). According to the New Thrive Learning Institute, affiliate marketing is one of the easiest and most profitable method for online businesses because it does not require its own experience and site, and only requires simple promotional techniques to convert the potential buyers into consumers (Institute, 2016).

The New Thrive Learning Institute likens affiliate marketers to sales people, the difference is that all sales activities occur in cyberspace without involving door to door components. Furthermore, Fill (2013) explains that affiliate marketing schemes are based on networks and sites that display advertisements or links. Affiliate members' website visitors are directed to the main website of the affiliate marketing program. If this visit leads to sales, the affiliate member will get commission.

According to Ryan and Jones, in practice affiliate marketing often overlaps with other internet marketing, because affiliate marketers often use internet advertising methods in general such as search engine optimization (SEO), paid search engine marketing, email marketing, and display advertising on several occasions. On the other hand, affiliate marketers also use the simpler marketing techniques such as displaying reviews of the products or services offered by the company (Ryan \& Jones, 2009).

In 2002, Fill introduced the concept of DRIP in marketing communication, namely Differentiate so that products or services stand out in that category. Reinforce to consolidate and strengthen the past messages and experiences. Inform with the aim of informing and suggesting the availability of the product service and its features. Then, persuade to encourage purchases. Sanjaya and Tarigan also emphasize that successful organizations know that they are largely determined by the strong value of differentiation of business organization products or services. Sanjaya and Tarigan argue that the digital world provides equal opportunities for every products to be known. This has become even more remarkable with the emergence of independent online blogs and sites in providing assessments of products and services (Sanjaya \& Tarigan, 2009).

Meanwhile, a study entitled Affiliate Marketing's Future in India, published by the Indian Journal of Science and Technology in February 2015, considered that affiliate marketing is one of the online marketing tactics that was heavily adapted by online companies in western countries, such as the United States (Prabhu \& Satpathy, 2015). 
The trend of using affiliate marketing strategies is predicted to continue to increase in the next few years throughout the world, both for B2C and B2B businesses.

In the previous study, the researchers analyzed the implementation of affiliate marketing program carried out by various businesses in India, such as online shopping companies, matchmaking sites, OTA, and job seeking sites. The tour and tourism sectors are one of the fastest growing sectors in the digital world (Prabhu \& Satpathy, 2015). The growth of the tour and tourism industry in India was recorded as the second fastest growth in the world. Based on the report released by Deutsche Bank, the growth of the tour and tourism industry in India was predicted to reach US $\$ 111$ billion by 2020.

The affiliate marketing program is implemented by several well-known OTA companies in India, namely MakeMyTrip.com, TripAdvisor.com, Yatra.com, Expedia.in, and Ixigo.com. The commission system applied by this OTA also varies, ranging from giving commission to $50 \%$ per booking and the implementation of giving commissions per click system. The result of the analysis from this study concluded that affiliate marketing will grow rapidly in the next few years. This strategy can provide opportunities for small-scale businesses and individuals to capture revenue.

The research related to affiliate marketing has also been carried out by Stefan Schwarz from Modul University Vienna in 2011. The researcher focused on analyzing how oeticket.com ran its affiliate marketing program. The application of affiliate marketing programs is very competitive, while the programs implemented by oeticket.com are considered still need improvement. The researcher then analyzed the various existing affiliate marketing programs, namely Amazon.com, Tiketsnow.com, and oeticket.com. The result of this study is that oeticket.com is recommended to join an affiliate network or join a third party to be able to take advantage of the latest affiliate marketing technologies such as automatic registration systems and tracking the transactions that occur.

The difference between the previous studies with this study is that the company taken is PegiPegi, a company in the country that actively engages in performing affiliate marketing activities. In carrying out the program, pegipegi also embraced affiliate marketers from various groups, namely individual affiliate marketers as well as companies (B2B and C2C) with different commission schemes. Whereas in the previous studies the companies studied in affiliate marketing activities are only focused on B2C and B2B. the researchers want to see how affiliate marketing activities are carried out specifically the techniques used when doing personal sales to their buyers.

\section{Methodology}

Bogdan and Taylor (1975) defined qualitative methodology as a research procedure that produces descriptive data in the form of written or oral words from people and observable behavior. According to them, this approach is directed at the background and the individual holistically (intact) (Bogdan \& Taylor, 1975). Whereas there qualitative researchers, Denzin and Lincoln stated that qualitative research is research that uses natural settings, with the intention of interpreting the phenomena that occur and are carried out by involving various existing methods, in this case the common methods used are interviews, observations, and utilization of documents. In collecting data, the researchers conducted gradual interviews with the affiliate marketing team and affiliate marketers (Denzin \& Lincoln, 1987). 
The interviewees for this study are: Alliance Marketing Supervisor Pegipegi, Kristy Karlinda; Alliance Officer Pegipegi, Qory Kurnia; DKI Jakarta-based Affiliate Marketer Representative -- Wahyu Wardhana, 33 years old, a private employee; West Java Affiliate Marketer Representative -- Irma Devi Silvia January, 26 years old, honorary teacher; Central Java Affiliate Marketer Representative -- Abdul Latief, 25 years old, a farmer; Marketing Expert -- Teguh Poeradisastra, who works as Managing Director of SPOT Corporate Communication (SWA Group) and Lecturer in The London School of Public Relations STIKOM Postgraduate Program. After that, the next step to do is the analysis by comparing the results of interviews with the literature data as secondary data.

\section{Results and Discussion}

According to Ryan and Jones, the simplest definition of affiliate marketing is an activity to bring traffic from a site to another site with the aim of getting rewards. The parties referred to as affiliate marketers are individuals, companies managed by individuals, or large organizations that use their online sites to invite traffic from cyberspace to visit their sites in order to earn commissions in return. In carrying out the program, Pegipegi also embraced affiliate marketers from various groups, namely individual affiliate marketers and also companies (Ryan \& Jones, 2009). As revealed by Alliance Officer Pegipegi, Qory Kurnia, currently Pegipegi organizes affiliate marketing programs for $\mathrm{B} 2 \mathrm{~B}$ and $\mathrm{C} 2 \mathrm{C}$. What makes the two programs different is the treatment provided and the commission scheme provided.

"There are 7 B2B programs like Wego and Flip It. The transaction from B2B is more than the others. But now we focus on both because we are still trying to see which one is good. For C2C affiliate marketers, we focus on people who are really looking for income from side jobs" (Interview with Qory Kurnia, June 15, 2017).

Affiliate marketing tools that are widely used for C2C based on 2016 data are text link and banner (94\%) and widget (6\%). While for most sales is hotel. The superior use of text link and banner by affiliate marketers is in line with the statement of marketing expert Teguh Poeradisastra, who thinks that the text link and banner are the easiest to see and just need to be clicked on, so it's not surprising that most online marketers use them.

The pegipegi affiliate marketing program is open to anyone who wants to join. The method is quite easy, according to him, the prospective affiliate marketers can simply register on pegi-pegi site, join the Facebook Page of Pegipegi Affiliate Marketing, regularly visit the blog of Pegipegi affiliate marketing, then they will receive a newsletter containing information about the latest affiliate marketing news.

In accordance with the definition proposed by Ryan and Jones, the affiliate marketers are pursuing commissions in return for their efforts to market pegipegi products. McPheat also thinks that affiliate marketing strategies benefit both parties, namely business people and the affiliate marketers. The benefits of business people come in the form of the visits to their online sites and consumers, while the benefits of affiliate marketers come in the form of commissions (McPheat, 2011). Qory assesses the number and contribution of the affiliate marketers are increasing from year to year, as well as the percentage of the revenue given by the affiliate marketers.

The purpose of implementing the affiliate marketing program of Pegipegi is in line with the statement from Jakarta's representative affiliate marketers, Wisnu, who stated that the profit he gained from becoming Pegipegi affiliate marketers was a fair 
value. Another benefit that he gets by marketing hotel is knowing a lot of keywords that can affect purchases. The same thing was also expressed by Latief, an affiliate marketer representative of Central Java, who enjoyed the extra money.

Meanwhile, the affiliate representative of West Java, Irma, stated that another benefit she felt was knowing how to create a blog, marketing products through FB Ads and AdWords, which affected the visits to her personal blog.

According to marketing expert Teguh Poeradisastra, "The main motive for people to market is income. The second is the freedom of time. According to him, the freelance pegipegi affiliate marketers can market the products at their leisure time, anytime and from anywhere, as long as there is internet access. However, he suggested that it would be much better if pegipegi provided additional incentives in the form of OTA products services for affiliate marketers, so that affiliate marketers had confidence, bonding, and experience with the products/services they marketed" (Interview with Teguh Poeradisastra, on August 24, 2017).

Furthermore, Wisnu, who has joined as pegipegi affiliate marketer since February 2016, stated that he had received commission more than Rp 500 thousand for the sale of more than 10 hotels through an affiliate link which was marketed on two of his blogs, namely http://bookinghotelmurah.net/ and http://hotelmurahdibali.net/.

Wisnu initially joined as pegipegi affiliate marketer because he was interested in the large commission of nearly $50 \%$ and the minimum withdrawal of his collected commission was small, which was only Rp 200,000. Meanwhile, Irma joined as affiliate marketer since May 2017 because she was interested in the commission that can reach $75 \%$. In addition to getting benefit from the affiliate marketing program, the three informants still considered that there were some disadvantages of Pegipegi affiliate marketing program.

According to Wisnu, the disadvantage is that if there is no order in one year through an affiliate link that has been given by Pegipegi, then they are taken out from the affiliate program. According to him, this is very strange, in fact Pegipegi gets the benefit of advertising for free on blogs that have Pegipegi affiliation. Then the second disadvantage is that there is no commission for buyers who only register on pegipegi site through a reference link, without booking the hotel room. Irma, on one hand assesses the lack of the affiliate marketing program is that it does not tell about the infringements that must be avoided to the regristrant to market Pegipegi affiliate promo.

Meanwhile Abdul highlighted the lack of the amount of commission given to the affiliate marketers because it was sometimes cut by discount, as the lack of pegipegi affiliate marketing program. The lack of pegipegi affiliate marketing program is also highlighted by the marketing expert Teguh Poeradisastra who argues that Pegipegi has less face-to-face sharing session with its affiliate marketing partners so that they are less in terms of closeness. Then in terms of experience, Teguh suggested Pegipegi to give a gift in the form of traveling package for its affiliate marketing partners in order to get experience from Pegipegi products or services.

In 2002, Fill introduced the concept of DRIP in marketing communication, namely Differentiate so that products or services stand out in that category. Reinforce to consolidate and strengthen past messages and experiences. Inform with the aim of informing and suggesting the availability of the product/service and its features. Then, persuade to encourage purchases. Both Pegipegi and the three affiliate marketers interviewed by the researchers said that they applied the DRIP concept in running affiliate marketing program and while becoming affiliate marketers. 


\section{Differentiate}

According to Qory and Kristy, one of the ways to distinguish Pegipegi affiliate marketing programs with other OTAs is often inform affiliate marketers that Pegipegi offers the highest affiliate commission of up to $75 \%$. Pegipegi also often holds competitions among affiliate marketers to increase sales and motivate them as affiliate marketers. The implementation of Pegipegi Affiliate Marketing Program is considered good by marketing expert Teguh Poeradisastra, but he warns that all programs can be followed easily by other companies. He argues, Pegipegi needs to create attachment with its affiliate marketers, especially considering that affiliate marketers are individuals who are free to jump at any time to the company which they think are more profitable or more pleasant. While from the affiliate marketers perspective, based on the three informants answers, then to distinguish the way they market Pegipegi products to the prospective buyers is by playing on the content, such as using the most searched keywords, highlighting the advantages of pegipegi and the images taken from Pegipegi. Reinforce

In strengthening the message about Pegipegi products to prospective buyers on their blog, two informants provided detailed information about the products and played on the keywords. While one informant chose to highlight the advantages of Pegipegi in his blog.

Inform

In informing the availability of pegipegi products to prospective buyers, Wisnu relied on the affiliate text link on his blog, while Latief used Google Ads to promote his blog, and Irma highlighted the advantages of Pegipegi on her blog.

Persuade

The two affiliate marketing informants rely on the right keywords on their blogs to persuade the prospective buyers. While Latief added by using Google Ads. Another case with Irma, he chose to highlight the advantage of Pegipegi on his blog. The steps taken by the three affiliate marketing marketers were justified by the marketing expert Teguh Poeradisastra. However, he stressed that smart affiliate marketers would recommend subtly, with persuasion, not with bombastic words. For example, convincing with data and logic, as well as personal experiences or testimonials of others.

The main digital media commonly used by affiliate marketers is online sites and blogs. However, according to Ryan and Jones, in practice the affiliate marketing often overlaps with other internet marketing, because affiliate marketers often use the common internet advertising method such as search engine optimization (SEO), paid search engine marketing, email marketing, and display advertising on several occasions. In this case study, the researchers try to find out what digital media are used by affiliate marketers, and how the informants maximize the use of digital media of their choice (Ryan \& Jones, 2009).

Digital Media

The three informants relied on blogs as the digital media that they used to market Pegipegi products. Then to promote their blogs, the three informants used Google Ads, FB Ads, and SEO. Even though blog is the primary digital media of the three informants' choice in this study, the marketing expert Teguh Poeradisastra advised affiliate marketers to explore the use of website because he considered the media is free to give the best review through words and also images.

Interactivity 
Although digital media is known as a medium that facilitates two-way communication or interactivity between the account owners and the account visitors, but in the case of Pegipegi affiliate marketers, the three informants have never interacted with their buyers on the blog media. The buyer only clicks on the text link or banner of Pegipegi product that is provided by the informants on their blogs and directly conduct purchases on pegipegi site.

Personalization

In understanding the message they delivered on the blog, Wisnu chose to play on the keywords while Latief and Irma sold the advantages of Pegipegi on their blogs. According to Ryan and Jones, affiliate marketers can attract consumers to visit their website or blog by using marketing email, mastering searching techniques so that their blogs can achieve search engine result page (SERP) ranking. Reliable affiliate marketers can even educate consumers and direct them to make purchases. In this case study, the researchers looked for what abilities the three informants had so that they could be more superior to other affiliate marketers (Ryan \& Jones, 2009).

Affiliate Marketing Tools

In marketing Pegipegi products on their blogs, the three informants used the text link and banner most often. Search box and widget are less favorite choices. Another advantage possessed by the three informants is their understanding on the basic functions of affiliate marketing tools.

Partnership and Collaboration

Two informants put the extra money as the main benefit of becoming an affiliate marketer, followed by the knowledge of digital marketing. Besides getting the benefits from affiliate marketing programs, the three informants still considered there were some disadvantages of Pegipegi affiliate marketing program. According to Wisnu, the disadvantage is that none of the order within one year through an affiliate link that has been granted by Pegipegi, then they are taken out from the affiliate program. According to him, this is very strange, in fact Pegipegi is benefited by free advertising on affiliate partner blogs. Then the second disadvantage is that there is no commission for buyers who only register on Pegipegi site through a reference link, without booking a hotel room. Irma on one hand assesses the lack of the affiliate marketing program is that they do not tell the registrant what infringements should be avoided to market Pegipegi affiliate promo, whether it's after being accepted to become an affiliate marketer or a statement in pegipegi affiliate account. Meanwhile Abdul highlighted the lack of the amount of commission given to affiliate marketers because it was sometimes cut by discount, as the disadvantage of Pegipegi affiliate marketing program.

In practice affiliate marketing often overlaps with other internet marketing (Ryan \& Jones, 2009), because affiliate marketers often use internet advertising methods in general such as search engine optimization (SEO), paid search engine marketing, email marketing, and display advertising on several occasions. This is in accordance with what the informants said that in attracting audiences, they must have knowledge of SEO, SEM and content creation. As stated below, the three informants answered that the basic skills/understanding of digital marketing are beneficial to their activities as affiliate marketers. In addition to the basic capabilities of marketing, two of the three informants spent special time to carry out their activities as affiliate marketers. For example Wisnu, because this is marketing through a blog on the internet, the SEO ability for blogs to get the best position in search engines and create unique articles with buying keywords is very necessary. In carrying out his role as an affiliate marketer, 
Wisnu spends 1 - 2 hours per week uploading articles and inserting affiliate text links. In addition to the text link, he also uses banner and widget to market Pegipegi products. $\mathrm{He}$ also spends the time to search for details about the products available in Pegipegi and what purchase keywords are the most sought by people on search engine so that he can insert them in his blog articles. Another quality that he has as an affiliate marketer is the commitment to become Pegipegi affiliate marketer for a long time in the future. Wisnu even plans to make the commission from affiliate marketer as the main income.

As an affiliate marketer, Irma learns about marketing through blogs and advertises through FB Ads and Adwords. She also highlighted the advantages of Pegipegi in corporate to attract the prospective buyers. Even though she doesn't spent time specifically to update the contents of her blog or even has specific sales target, but Irma commits to become an affiliate marketer in the long run.

Just like Wisnu, Abdul pays attention to the keywords or buying keywords that are most often searched for on search engine. The information that he used on his blog includes selling the excellence of Pegipegi. Abdul claimed that he did not have specific sales target. But he spends at least 15 minutes per day to evaluate the performance of his blog and plans to make the affiliate marketing profession as one of the sources of income for the long term. According to the marketing expert interviewed by the researchers, text link and banner are the easiest to see and just need to be clicked. However, the text link and banner are in the upstream, the audiences just know that there are links and banners if they are already on the blog or website. To attract netizens who previously have not known the affiliate marketer's blog or online site, they need to have the knowledge of SEO and SEM to achieve high search engine result page (SERP) ranking (pages 1-3 in the search results through query). Affiliate marketers also need to know what keywords are in the minds of the target audiences when they are looking for or need something. Furthermore, marketers must also be able to develop content that captivates the reader (content creation). The key is knowing what is important and what is the concern/interest of the audiences. By knowing the concern and interests of the audiences, affiliate marketers can arrange the content that interests them.

\section{Conclusion}

The affiliate marketers perform the sales of their participants by using blog as digital media, text links and banners as their affiliate marketing tools. Other sales techniques used are their extra efforts and more initiatives conducted to learn about the functions of affiliate marketing and internet marketing tools, such as SEO, the most popular keywords related to tourism, and using Google Adwords and FB Ads to capture potential audiences in the virtual world to visit their blog. In addition to the basic capabilities and knowledge of digital marketing, the affiliate marketers interviewed have high and long-term commitments as affiliate marketers by finding out what consumers want, manage their blogs regularly and analyze what works and what doesn't work, as well as compile blog content that is quite interesting for the audiences. For example by paying attention to the keywords or buying keywords that are most frequently searched for in search engine and able to develop content creation in order to attract readers.

Based on the results of data analysis obtained during the study, there are several steps that can be conducted by the Alliance Marketing Division of Pegipegi to maximize the role of its affiliate partners, namely: providing basic understanding on how the affiliate marketing system works to avoid the disappointment of the affiliate 
marketers about calculating commission; providing basic knowledge to the affiliate marketers about how to do marketing by using blogs, FB Ads, Google Ads, and SEO to maximize their marketing activities. This knowledge can be given when new affiliate marketers join and also periodically; spending time regularly to conduct discussions or question and answer sessions between Pegipegi and the affiliate marketers so that they get the latest tips and tricks on how to become super affiliates, and strengthen Pegipegi relations with their affiliate marketers; holding sales competition for affiliate marketers wuth the award of holidays so that they get real experience of the products and services sold by Pegipegi.

\section{Acknowledgments}

The authors would like to thank: Pegipegi and all the Affiliate Marketings involved in this research making.

\section{References}

Belch, G. E., \& Belch, M. (2015). Advertising and Promotion: An Integrated Marketing Communications Perspective (Global Edi). United Kingdom: McGraw-Hill Education.

Bogdan, \& Taylor. (1975). Metodologi Penelitian Kualitatif. Bandung: Remadja Karya.

Denzin, N. K., \& Lincoln, Y. S. (1987). Handbook of Qualitative Research. Thousand Oaks: SAGE Publications.

Fill, C. (2013). Marketing Communications: brands, experiences and participation (6th ed.). United Kingdom: Pearson.

Institute, N. T. L. (2016). Millionaire Mindset. Morrisville, North Carolina: Lulu Press, Inc.

Kaufman, I., \& Horton, C. (2015). Digital Marketing: Integrating Strategy and Tactics with Values: A Guidebook for Executives, Managers, \& Students. United Kingdom: Routledge.

Kingsnorth, S. (2016). Digital Marketing Strategy: An Integrated Approach to Online Marketing (1st ed.). USA: Kogan Page.

Kotler, P. (2001). Kotler on Marketing: How to Create, Win and Dominate Markets. United Kingdom: Simon \& Schuster UK Ltd.

McPheat, S. (2011). Eselling: The Alternative Way to Prospect and Sell for Sales Professionals: How to Use the Internet for Prospecting, Personal Branding, Networking and for Engaging the C-Suite Decision Maker. United Kingdom: Troubador Publishing Ltd.

Nursastri, S. A. (2016). Saatnya "Travel Agent" Konvensional Merambah Dunia Digital.

Prabhu, S., \& Satpathy, T. (2015). Affiliate Marketing's Future in India. Indian Journal of Science and Technology, 8(S4), 278-282.

Putri, D. W., \& Maulida. (2017). Analisis Strategi Perencanaan Pesan Pada Akun Instagram E-Commerce @ thekufed. Jurnal The Messenger, 9(1), 70-78.

Ryan, D., \& Jones, C. (2009). Understanding Digital Marketing: Marketing Strategies for Engaging the Digital Generation. London: Kogan Page.

Sanjaya, R., \& Tarigan, J. (2009). Creative Digital Marketing. Jakarta: PT Elex Media Komputindo.

Setiawan, B. (2016). Target Wisatawan Mancanegara dalam Dua Tahun Jokowi-JK. 